\title{
PKM Teknologi Pembangkit Listrik Tenaga Floating Hydro Di Kecamatan Wungu, Kabupaten Madiun
}

\author{
Budi Artono**1, Rakhmad Gusta Putra ${ }^{2}$, Hanifah Nur Kumala Ningrum ${ }^{3}$ \\ ${ }^{1,2}$ Politeknik Negeri Madiun; Jl. Serayu no.84, telp.(0351) 452970 fax. (0351) 492960 \\ ${ }^{3}$ Program Studi Teknik Listrik, Politeknik Negeri Madiun \\ e-mail: *11 budiartono@pnm.ac.id , ${ }^{2}$ gusta@pnm.ac.id , ${ }^{3}$ hanifah.nkn@gmail.com
}

\begin{abstract}
Abstrak
Desa Karangrejo merupakan salah satu Desa di Kecamatan Wungu, Kabupaten Madiun, Provinsi Jawa Timur yang terletak $\pm 5 \mathrm{~km}$ dari kota pusat pemerintahan Kabupaten Madiun. Desa ini memiliki luas wilayah sekitar \pm 351 Ha dengan jumlah penduduknya berkisar \pm 4,098 Jiwa. Konsumsi listrik di Desa Karangrejo setiap tahun terus meningkat, seiring bertambahnya penduduk, pertumbuhan ekonomi dan pola konsumsi energi yang terus bertambah. Komsumsi listrik yang begitu besar akan menjadi suatu masalah bila dalam penyediaannya tidak sejalan dengan kebutuhan. Potensi yang besar dimiliki Desa Karangrejo yaitu terdapat aliran air irigasi yang melimpah di sekitar pemukiman dan kawasan pertanian. Potensi aliran air irigasi yang begitu deras sampai saat ini belum termanfaatkan secara maksimal dan mayoritas masih hanya digunakan untuk proses pengairan sawah. Kegiatan pengabdian kepada masyarakat melalui program kemitraan bagi masyarakat warga Desa Karangrejo Kecamatan Wungu, Kabupaten Madiun ini dititik beratkan pada pemberdayaan masyarakat melalui pengenalan dan pengembangan teknologi dengan memanfaatkan aliran air irigasi untuk pembangkit listrik. Jenis pembangkit listrik yang sesuai dengan kontur di Desa Karangrejo ini adalah tipe pembangkit listrikdengan tenaga floating hydro dengan memanfaatkan aliran air irigasi sebagai sumber utama pembangkit listrik. Harapannya dengan pelatihan ini warga dapat memanfaatkan potensi alam yang ada serta dapat mengelola menjadi pembangit listrik mandiri dengan biaya murah.
\end{abstract}

Kata kunci : Pembangit Listrik, Tenaga Floating Hydro, Madiun

\section{PENDAHULUAN}

Sumber energi di Indonesia didominasi oleh sumber energi yang tidak dapat diperbaharui yang berasal dari energi fosil, seperti Bahan Bakar Minyak (BBM), Batubara dan Gas Bumi. Data cadangan minyak pada tahun 2013 sebanyak 3.7 triliun barel, produksi atau pengeboran 882 ribu barel per hari, refining 1.072 juta barel per hari, dan konsumsi 1.623 juta barel per hari (EBTKE, 2016). Dilihat dari jenis pembangkit listriknya, sekitar $87 \%$ diantaranya masih menggunakan bahan bakar fosil yang sebenarnya akan habis dalam kurun waktu beberapa tahun kedepan (BPPT, 2017). Diperlukan sebuah inovasi untuk menyiapkan Indonesia untuk menjadi negara yang mandiri dalam hal energy.

Pembangkit listrik tenagaFloating Hydro merupakan salah satu sumber energi terbarukan yang dapat memberikan manfaat yang besar bagi masyarakat untuk memenuhi kebutuhan energi listrik. Salah satu kelebihanpembangkit listrik ini diantaranya adalahtidak perlu mengeluarkan biaya tinggi untuk sistem transmisi daya dan perawatan lingkungan secara umum,karena implementasi sistemlangsung terintegrasidengan pemanfaatannya. Hasil dari energi listrik yang dihasilkan dapat digunakan untuk membantu masyarakat dalam menerangi kebutuhan rumah tangga. Selain itu dapat juga digunakan sebagai penerangan jalan, melihat di Desa Karangrejo masih banyak penduduk yang menggunakan listrik rumah untuk penerangan jalan serta di beberapa titik saat malam masih minim penerangan yang ada 
di jalan. Untuk mengatasi masalah tersebut, maka melalui Program Kemitraan Masyarakat ini dilakukan suatu penelitian dan pembinaan pemanfaatan potensi air irigasi melalui pembangkit listrik tenaga Floating Hydro guna mewujudkan kemandirian energi masyarakat di Desa Karangrejo. Pemanfaatan aliran air irigasi nantinya dapat digunakan sebagai solusi alternatif untuk kebutuhan listrik Desa Karangrejo. Selain itu dengan program ini diharapkan Desa Karangrejo dapat menjadi Desa mandiri energi yang juga dapat membantu meningkatkan kualitas perekonomian masyarakat secara umum.

Desa Karangrejo merupakan salah satu desa di Kecamatan Wungu, Kabupaten Madiun, Provinsi Jawa Timur yang terletak $\pm 5 \mathrm{~km}$ dari pusatkota pemerintahan Kabupaten Madiun. Desa ini memiliki luas wilayah sekitar \pm 351 Ha dengan jumlah penduduknya berkisar \pm 4,098 Jiwa. Konsumsi listrik di Desa Karangrejo setiap tahunterusmeningkat, seiring bertambahnya jumlah penduduk, pertumbuhan ekonomi dan pola konsumsi energi yang terus bertambah. Komsumsi listrik yang begitu besar akan menjadi suatu masalah bila dalam penyediaannya tidak sejalan dengan kebutuhan masyarakat.

Potensi yang sangat besar pada desa di sekitar pemukiman dan kawasan pertanian belum dimanfaatkan menjadi sumber energi.Sampai saat ini aliran air irigasi hanya digunakan untuk mengaliri persawahan warga Desa Karangrejo dan belum di manfaatkan sebagai sumber energi terbarukan. Padahal saluran air irigasi yang letaknya disekitar pemukiman dan kawasan pertanian ini dapat dimanfaatkan untuk membuat sumber pembangkit listrik berupa pembangkit listrik tenaga Floating Hydro.
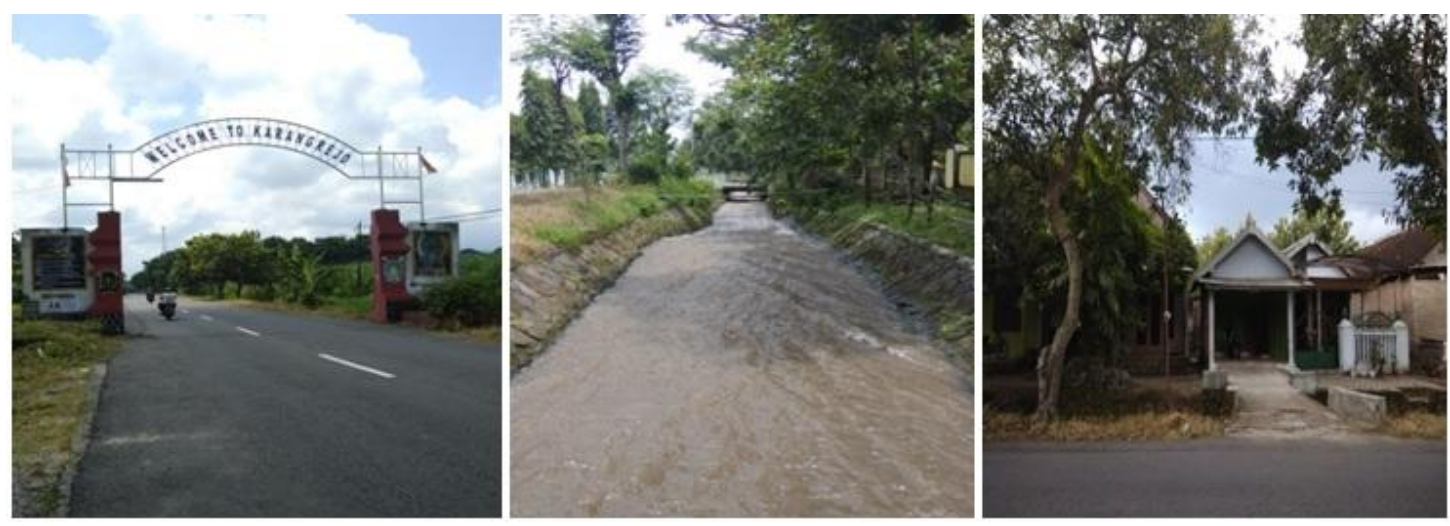

Gambar 1. (a) Akses jalan menuju Desa Karangrejo, (b) Potensi aliran air irigasi,(c) Lampu penerangan jalan masih menggunakan listrik rumah penduduk.

\section{METODE}

Metode pelaksanaan yang digunakan dalam Program Kemitraan Masyarakat ini adalah denganpemahaman partisipatif masyarakat terhadap pemanfaatan sumber daya alam dengan melihat kondisi dan potensi aliran air irigasi yang ada di Desa Karangrejo yang dapat dimanfaatkan untuk pembuatan pembangkit listrik tenaga Floating Hydro. Metode ini memiliki beberapa tahapan, yaitu :

\section{Identifikasi masalah dan Analisa Kebutuhan}

Pada proses identifikasi ini dilakukan dengan survey secara langsung dengan melihat kondisi dan potensi di Desa Karangrejo Kecamatan Wungu, Kabupaten Madiun, Provinsi Jawa Timur. Potensi aliran air irigasi yang cukup besardapat diubah kedalam bentuk energi listrik sebagai sumber energi alternatif. Kemudian dilakukan analisis kebutuhan, hal ini diharapkan agar kegiatan dapat berjalan lancar dan masyarakat mendapat manfaat serta pengetahuan danketrampilan baru dalam mengolah potensi aliran air irigasi tersebut. 
2. Penyusunan Program

Program yang menjadi prioritas adalah memberdayakan masyarakat Desa Karangrejo dalam mengolah aliran air irigasi menjadi sumber energi listrik, serta dapat menjadikannya energi alternatif guna mewujudkan kemandirian energi masyarakat Desa Karangrejo.

3. Pelaksanaan Program

a. Tahapan sosialisasi pengolahan aliran air irigasi menjadi sumber energi listrik

Pada tahap ini telah dilaksanakan kegiatan sosialisasi tentang pengolahan aliran air irigasi menjadi sumber energi listrik agar masyarakat memiliki pengetahuan dasar tentang cara pemanfaatan aliran air irigasi untukpembangkit listrik tenagaFloatingHydro.

b. Tahap Koordinasi antara Tim Peneliti dengan Kelompok Masyarakat

Pada tahap ini dilaksanakan koordinasi agar kelompok masyarakat dapat menjalankan, memonitoring dan mengembangkan program yang telah diusulkan.

4. Monitoring Program dan Evaluasi Program

Tahap monitoring program ini dilakukan untuk mengetahui kendala yang ada dalam proses pelaksanaan program, melihat perkembangan program yang dilaksanakan dan mencari solusi terhadap suatu permasalahan. Setelah tahap monitoring program selesai, kemudian dilakukan tahap evaluasi program. Hal ini dilakukan untuk mengetahui kekurangan dalam pelaksanaan program. Supaya dapat diperbaiki menjadi lebih baik lagi. Tahap ini dilakukan oleh mahasiswa, dosen peneliti dan masyarakat Desa Karangrejo.

5. Pelaporan

Tahap pelaporan dilakukan untuk mendokumentasikan kegiatan sehingga dapat di lakukan evaluasi secara menyeluruh dari rangkaian kegiatan yang sudah dilakukan.

\section{HASIL DAN PEMBAHASAN}

Pelaksanaan kegiatan dilakukan dengan model pelatihan dan sosialisasi dengan tatap muka bersama warga Desa Karangrejo Kecamatan Wungu Kabupaten Madiun. Pertemuan dilakukan dengan metode ceramah diskusi, pengenalan teknologi dan juga demo project alat Prototype pembangkit listrik dengan tenaga floating hydro. Kegiatan sosialisasi dilakukan di gedung balai desa diDesaKarangrejo. Sosialisasi ini dilakukan untuk memberikan pengetahuan terkini tentang teknologi pembangkit listrik dengan tenaga floatinghydro. Selain juga menjelaskan tentang teknologi secara umum, tim juga memberikan gambaran teknologi yang telah berhasil dibuat oleh Politeknik Negeri Madiun. Dengan kegiatan ini diharapkan warga lebih paham dan sadar akan energi baru terbarukan untuk bisa memanfaatkannya dan mengembangkan disekitar lingkungan mereka. Tahap selanjutnya adalah dengan mengaplikasikan teknologi bersama arahan dan bimbingan dari tim PKM dari Politeknik Negeri Madiun.

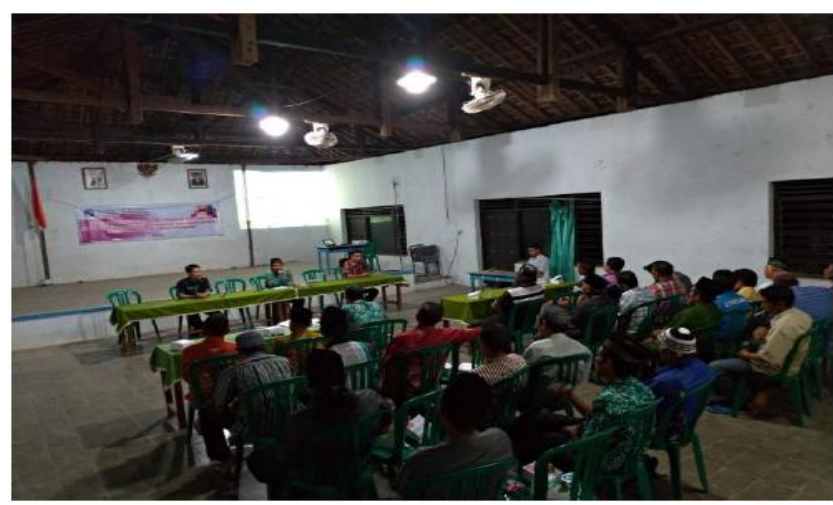

Gambar 2.Sosialisasi Oleh Tim Politeknik Negeri Madiun 


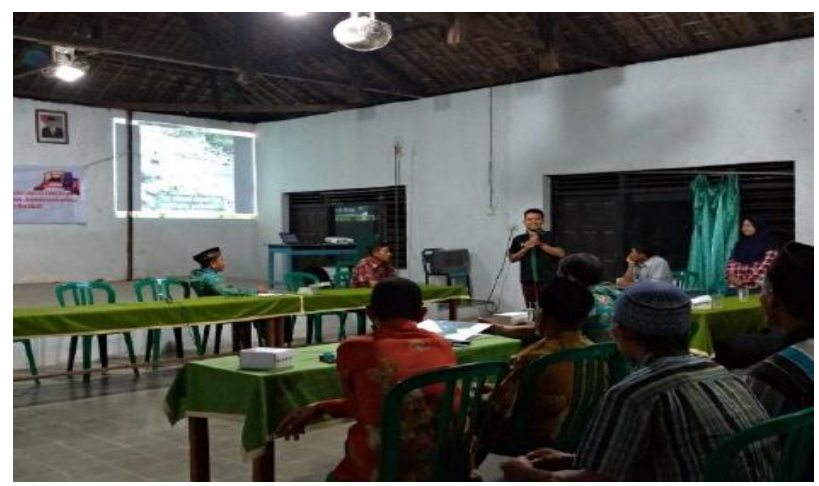

Gambar 3.Pemaparan Teknologi Floating Hydro

Setelah Tahapan sosialisasi dan pengenalan teknologi pembangkit listrik dengan tenaga FloatingHydroproses dilanjutkan dengan kegiatan pendampingan yang dibantu bersama tenaga mahasiswa untuk terus berkomunikasi dengan mitra. Hal ini dilakukan dengan harapan untukdapat menjaga komunikasi dan keberlanjutan program agar nantinya benar-benar dapat diterapkan oleh warga Desa Karangrejo Kecamatan Wungu Kabupaten Madiun. diantaranya :

Hasil dari kegiatan pengabdian masyarakat ini secara garis besar mencakup

1. Ketercapaian Tahapan Pengabdian Masyarakat.

2. Kesadaran masyarakat terkait dengan energi baru terbarukan dan penerapannyakhususnya pada Teknologipembangkit listrik dengan tenaga FloatingHydro.

Kegiatan ini adalah awal dari kemandirian energi, terutama listrik di Desa Karangrejo Kecamatan Wungu Kabupaten Madiun. tentu saja dengan satu kegiatan ini tidak akan cukup dikarenakan untuk mencapai Desa dengan kemandirian energi diperlukan peran aktif dari tim PKM serta partisipatif dari wargaDesa Karangrejo Kecamatan Wungu Kabupaten Madiun. Ketercapaian tahapan pengabdian kepada masyarakatini ditunjukkan dengan terlaksananya seluruh langkah dan metode pengabdian yang direncanakan,Kesadaran masyarakat terhadap energi terbarukan ditunjukkan dengan antusiasme peserta terhadap materi yang disampaikan. Berikut merupakan gambar perencanaan desain rangka pembangkit listrik tenaga Floating Hydro yangdigunakan.

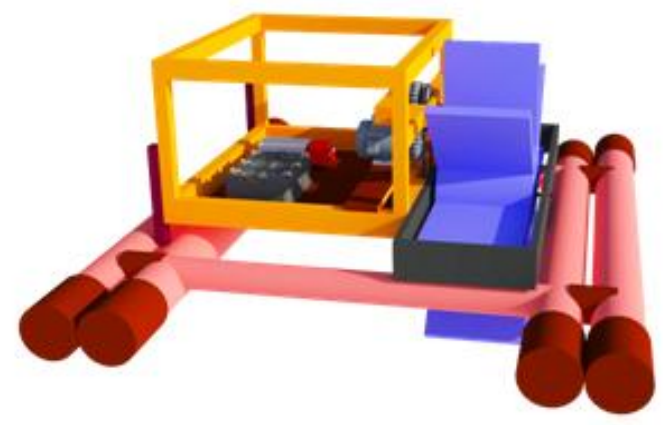

Gambar 4.Desain pembangkit listrik tenaga Floating Hydro 


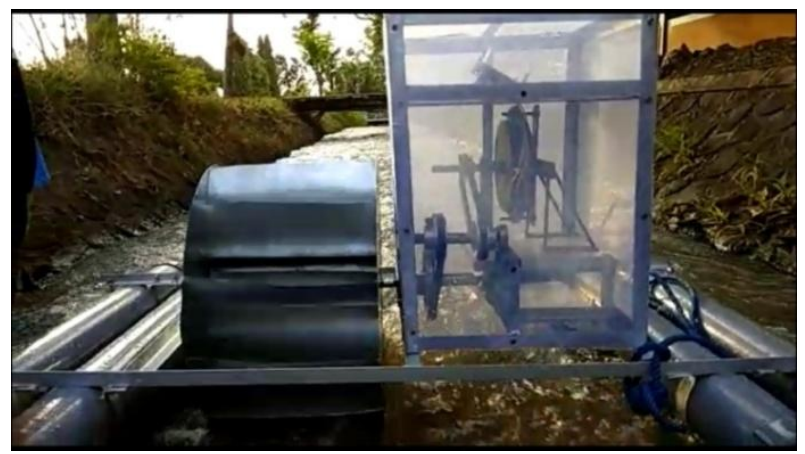

Gambar 6.Pembangkit listrik tenaga Floating Hydro saat dioperasikan

\section{KESIMPULAN}

Secara umum kegiatan ini dapat terlaksana dengan baik dan lancar. Program pengabdian kepada masyarakat telah berjalan sesuai dengan tahapan yang direncanakan mulai dari tahapan survei hingga pendampingan. Kesadaran masyarakat dapat dilihat dari antusiasme mereka dalam mengikuti proses bersama denganTim dari Politeknik Negeri Madiun. Untuk mencapai kemandirian energi dengan teknologi floating hydro tidak dapat langsung direalisasikan dikarenakan keterbatasan waktu dan dibutuhkan proses yang lebih panjang. Kegiatan ini telah mengawali untuk menyadarkan masyarakat tentang kemandirian energy dan menawarkan pilihan dan teknologi yang telah dikembangkan oleh tim PKM dari Politeknik Negeri Madiun.

\section{SARAN}

Saran untuk kegiatan selanjutnya adalah :

1. Pelaksanaan kegiatan dapat berkesinambungan sehingga tidak terputus pada satu kegiatan saja.

2. Mengimplementasikan secara langsung sehingga dapat dirasakan dampaknya di masyarakat

\section{UCAPAN TERIMA KASIH}

Penulis mengucapkan terima kasih kepada Politeknik Negeri Madiun yang telah memberi dukungan terhadap kegiatan PKM ini.

\section{DAFTAR PUSTAKA}

[1] EBTKE. (2016). JURNAL ENERGI Media Komunikasi Kementerian Energi dan Sumber Daya Mineral. Jakarta

[2] BPPT. 2017. Outlook Energi Indonesia 2016. Jakarta : Badan Pengkaji dan Penerapan Teknologi.

[3] https://arfansjunk.wordpress.com/2016/03/01/floating-hydro-turbine/ diakses pada 5 April 2019 